\title{
Aeromagnetic search for Cenozoic magmatism over the Admiralty Mountains Block (East Antarctica)
}

\author{
E. Armadillo, ${ }^{1}$ F. Ferraccioli, ${ }^{2}$ A. Zunino, ${ }^{3}$ E. Bozzo, ${ }^{4}$ S. Rocchi,${ }^{5}$ and P. Armienti ${ }^{6}$ \\ ${ }^{1}$ Dipartimento per lo Studio del Territorio e delle Sue Risorse, Università di Genova, V.le Benedetto XV 5,16132 Genova, Italy (egidio@dipteris.unige.it) \\ ${ }^{2}$ British Antarctic Survey, High Cross, Madingley Road, Cambridge CB3 OET, UK (ffe@bas.ac.uk) \\ ${ }^{3}$ Dipartimento per lo Studio del Territorio e delle Sue Risorse, Università di Genova, V.le Benedetto XV 5,16132 Genova, Italy \\ (andrea.zunino@dipteris.unige.it) \\ ${ }^{4}$ Dipartimento per lo Studio del Territorio e delle Sue Risorse, Università di Genova, V.le Benedetto XV 5,16132 Genova, Italy (bozzo@dipteris.unige.it) \\ ${ }^{5}$ Dipartimento di Scienze della Terra, Università di Pisa, Via di S. Maria 53-56126, Pisa, Italy (rocchi@dst.unipi.it) \\ ${ }^{6}$ Dipartimento di Scienze della Terra, Università di Pisa, Via di S. Maria 53-56126, Pisa, Italy (armienti@dst.unipi.it)
}

\begin{abstract}
Cenozoic magmatic rocks of the Transantarctic Mountains provide an important window on the tectonic and magmatic processes of the West Antarctic Rift System. Previous aeromagnetic investigations in northern Victoria Land have delineated Cenozoic volcanic and intrusive complexes assigned to the McMurdo Volcanic Group and Meander Intrusives over the Transantarctic Mountains. We present a new aeromagnetic anomaly map for the region north of the Mariner Glacier to study the extent and spatial distribution of these Cenozoic rocks over the previously unexplored Admiralty Mountains. The new map shows that the Meander Intrusives are restricted to the coastal region between the Malta Plateau and the Daniell Peninsula. However, the McMurdo Volcanic Group rocks extend further inland, and may delineate a hitherto unrecognised volcano-tectonic rift zone, extending as far north as the Trafalgar Glacier.
\end{abstract}

Citation: Armadillo, E., F. Ferraccioli, A. Zunino, E. Bozzo, S. Rocchi, and P. Armienti (2007), Aeromagnetic search for Cenozoic magmatism over the Admiralty Mountains Block (East Antarctica), in Antarctica: A Keystone in a Changing World - Online Proceedings of the $10^{\text {th }}$ ISAES, edited by A.K. Cooper and C.R. Raymond et al., USGS Open-File Report 2007-1047, Short Research Paper 075, 4 p.; doi: 10.3133/of2007-1047.srp075

\section{Introduction}

Major continental rifts are often associated with shortlived large igneous provinces of continental flood basalts, or long-lasting alkaline magmatic provinces. Northern Victoria Land (Figure 1) exposes the products of longlasting Cenozoic magmatism associated with the West Antarctic Rift System (WARS) (Behrendt, 1999). Plutons, dyke swarms, and volcanoes are relatively well exposed over an area of about $200 \times 80 \mathrm{~km}$ in northern Victoria Land (Rocchi et al., 2002a). Intrusive-subvolcanic rocks are known as the Meander Intrusive Group, while the volcanics are part of the McMurdo Volcanic Group (LeMasurier, 1990; Tonarini et al., 1997). These large alkaline intrusions are imaged by high-amplitude nearcircular aeromagnetic anomalies (Bosum et al., 1989) over the Southern Cross Block (Ferraccioli \& Bozzo, 1999) of the Transantarctic Mountains (TAM). Anomalies of this character have not been detected south of Campbell Glacier, suggesting that the Campbell Fault may mark the southern boundary of this Cenozoic alkaline intrusive province (Ferraccioli et al., 2000). Similar anomalies have however been imaged further to the south offshore beneath the Ross Ice Shelf, possibly delineating leaky transfer faults, which may link segments of the West Antarctic Rift System (Behrendt et al., 1996). The northernmost Cenozoic intrusion recognized so far is the Cape Crossfire Igneous Complex between Mariner Glacier and Borchgrevink Glacier (Rocchi et al., 2002b).

In this paper we present a new aeromagnetic anomaly map to address the spatial distribution of Cenozoic magmatic rocks for the previously unsurveyed Admiralty Mountains Block (Fig. 1).

\section{Regional setting}

A major phase of crustal extension in the WARS occurred in Cretaceous times (Lawver and Gahagan, 1994). This rifting phase was amagmatic in Victoria Land, and alkaline magmatism started later, in Middle Eocene times (Tonarini et al., 1997). The main denudation event over the TAM also occurred at this time (Fitzgerald, 2002). The amount of Cenozoic extension in the Ross Sea region is still debated. However, evidence from the Adare Trough region suggests at least $180 \mathrm{~km}$ of Cenozoic extension (Cande et al., 2000). Elements favouring plume-driven magmatism within the WARS include geochemical signatures, coupled with moderate crustal extension, doming over Marie Byrd Land and large-volumes of subglacial magmatism (Behrendt, 1999). However, over Victoria Land, strike-slip reactivation of the major inherited faults over TAM (Salvini et al., 1997; Ferraccioli and Bozzo, 1999) may have induced regional transtension, thereby triggering Cenozoic magmatism without invoking the existence of a deep-seated mantle plume (Rocchi et al., 2002a; 2005).

Two main constraints exist upon the timing of strike-slip faulting onshore over Victoria Land. One comes from pseudotachylytes along the Priestley Fault, formed at approximately $34 \mathrm{Ma}$ (Di Vincenzo et al., 2004). The other derives from apatite-fission track data over the Lanterman Fault, which attest to Middle to Late Eocene fault activity (Rossetti et al., 2003). 


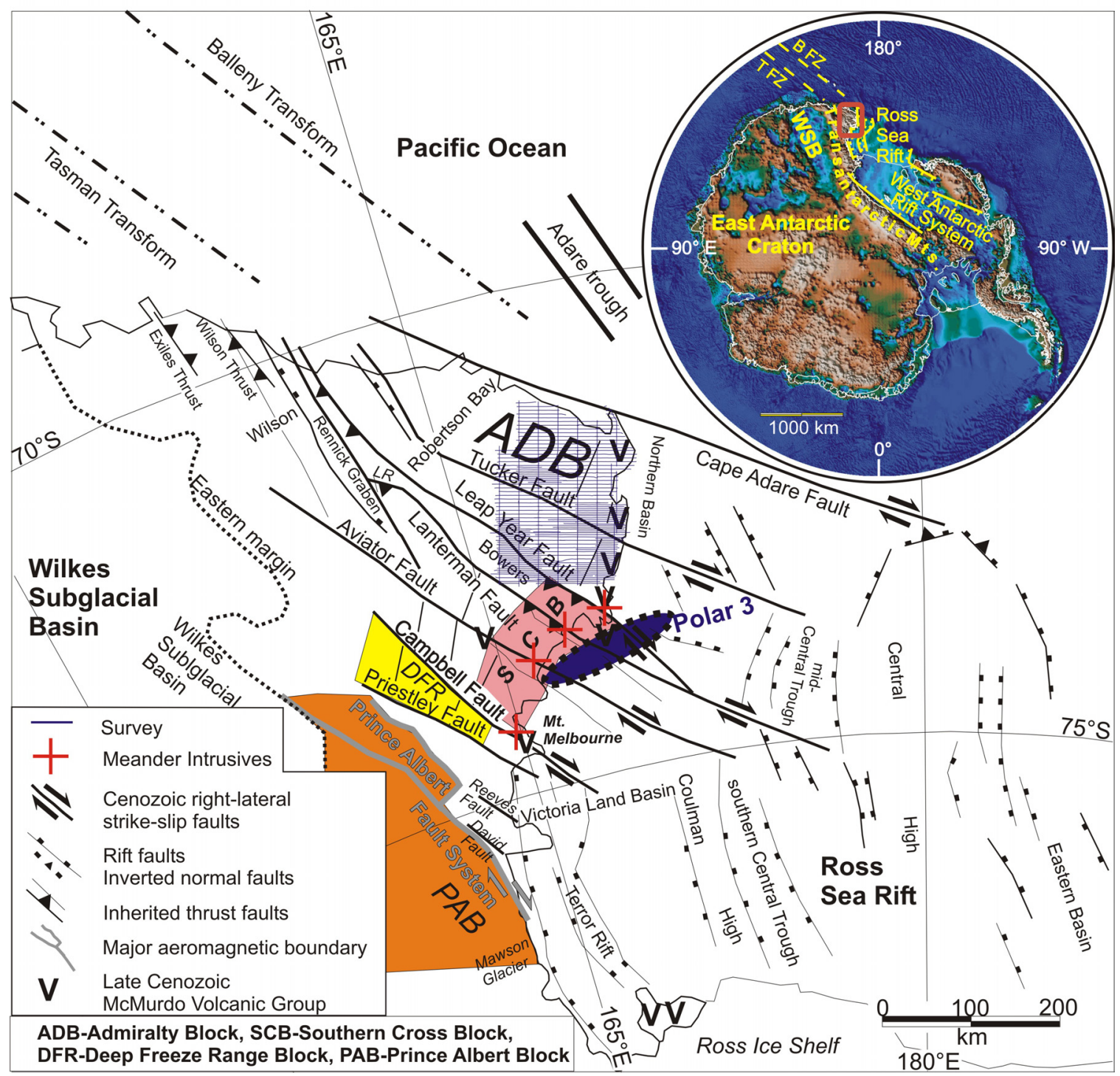

Figure 1. Tectonic sketch map of Victoria Land (modified from Ferraccioli and Bozzo, 2003). Note the location of the new aeromagnetic survey over the Admiralty Mountains Block targeting the northern extent of the alkaline Cenozoic magmatic province of the TAM. BFZ: Balleny Fracture Zone; TFZ: Tasman Fracture Zone.

Sequential tectonic activation in adjacent crustal blocks has been proposed to explain the diachronous magmatic activity, which appears to young northwards towards the Admiralty Mountains Block (Rocchi et al., 2006).

\section{Aeromagnetic survey}

An aeromagnetic survey was performed during the 2001-2002 Italian Antarctic campaign to investigate magmatic patterns north of Mariner Glacier over the Admiralty Mountains region (Armadillo et al., 2006). Layout and set-up of the new MAGANTER helicopterborne aeromagnetic survey closely resembled the one adopted for adjoining GITARA (Bozzo et al., 1999) and GANOVEX surveys (Damaske, 1994). Line spacing was therefore set to $4.4 \mathrm{~km}$ with tie lines $22 \mathrm{~km}$ apart. More detailed, $2.2 \mathrm{~km}$ line-interval sections were also flown over selected areas. Nominal survey flight altitude was $2700 \mathrm{~m}$. Some areas were flown at higher altitude (3000 and $3500 \mathrm{~m}$ ), owing to the high elevations of the Admiralty Mountains. Overall $10947 \mathrm{~km}$ of usable line data were collected over an area of $32000 \mathrm{~km}^{2}$. Aeromagnetic data processing included standard steps such as post-processing of GPS data, magnetic base station correction, IGRF removal and levelling. This was followed by microlevelling in frequency domain (Ferraccioli et al., 1998). The resulting aeromagnetic anomaly map is shown in Figure 2. 


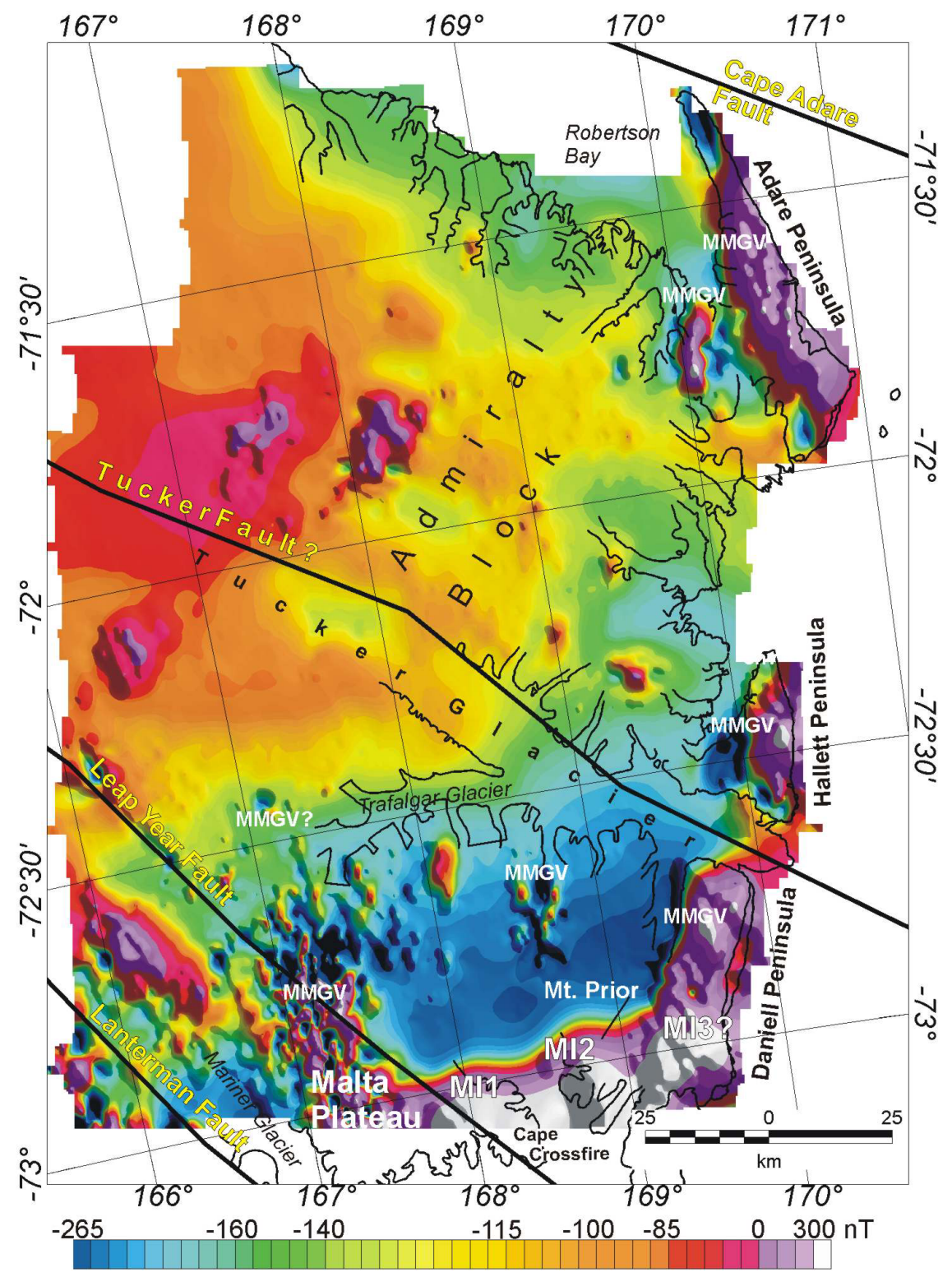

Figure 2. New aeromagnetic anomaly map of the Admiralty Mountains region. The main aeromagnetic anomaly patterns are identified and labelled.

\section{Aeromagnetic patterns}

The new aeromagnetic anomaly map clearly images Cenozoic McMurdo Volcanic Group (MMGV) rocks. High-amplitude positive aeromagnetic anomalies, with short-wavelengths trace the shallow volcanic rocks from their exposures across ice-covered areas of the Daniell Peninsula, south of the Tucker Fault and along the Hallett Peninsula to the north. A third region of similar anomalies is detected over the Adare Peninsula and overlies outcrops of similar volcanic rocks, south of the Cape Adare Fault. Magnetic trends within these three regions are N-S to NNW-SSE oriented and are parallel to the strike of the offshore rift basins (e.g. the northern Basin in Figure 1). This suggests that the volcanic rocks were emplaced along coastal fault zones forming the TAM rift flank.
However, an exception to this is seen north of the Malta Plateau, where an alignment of high-frequency anomalies delineates a largely unexposed area of Cenozoic volcanism, which extends considerably further inland, perhaps as far as the Trafalgar Glacier. We speculate that this may represent a hitherto unrecognized volcanotectonic rift zone. At the southern edge of this feature, a prominent aeromagnetic anomaly with amplitude over $800 \mathrm{nT}$ and wavelength of about $20 \mathrm{~km}$ (MI1), delineates the buried northern extent of the Cape Crossfire Igneous Complex (Rocchi et al., 2002b). Two comparable anomalies can be detected further to the east. One lies south of Mt Prior (MI2), where Cenozoic dyke swarms have been found (Rocchi et al., 2003), and may image another buried Meander Intrusive. A third possible 
intrusion is harder to detect (MI3?), but may underlie the volcanic rocks of the southern Daniell Peninsula. The ENE-WSW trend of these three aeromagnetic anomalies is highly oblique to the N-S to NNW-SSE trend of the volcanics or the NW-SE trend of the major strike-slip faults. However, it lies parallel to the prominent Polar 3 anomaly (Fig. 1), detected from previous aeromagnetic data offshore (Bosum et al., 1989; Ferraccioli and Bozzo, 1999). Several contrasting aeromagnetic patterns can also be recognized over the Paleozoic basement rocks (Finn et al., 1999; Ferraccioli et al., 2002; Federico et al., 2006). However the interpretation of these anomalies is beyond the scope of this paper which focuses exclusively on the Cenozoic magmatic and tectonic patterns.

\section{Conclusions}

A new aeromagnetic anomaly map images the extent and nature of Cenozoic magmatic rocks over the Admiralty Mountains Block of the TAM. Major Cenozoic alkaline intrusions assigned to the Meander Intrusives are restricted to the area between the Malta Plateau and the Daniell Peninsula. These rocks are not detected further north indicating tectono-magmatic segmentation over this region of the TAM. Cenozoic volcanic rocks belonging to the McMurdo Volcanic rocks lie parallel to the offshore rift basins and appear to extend inland of the TAM rift flank, between the Malta Plateau and Trafalgar Glacier, where they delineate a possible volcano-tectonic rift zone.

Acknowledgements Logistic and financial support has been provided by PNRA. The thoughtful and constructive reviews of Marta Ghidella, Alexander Golynsky and an anonymous reviewer helped to improve this manuscript. The co-editor Philip Kyle is gratefully acknowledged for providing constructive suggestions.

\section{References}

Armadillo E., E. Bozzo, G. Caneva, F. Ferraccioli \& G. Tabellario (2006), Recent aeromagnetic and deep electromagnetic exploration projects in East Antartica, Terra Antartica Reports, 12, 167-176.

Behrendt, J.C. (1999), Crustal and lithospheric structure of the West Antarctic Rift System from geophysical investigations - a review, Global and Planetary Change, 23, 25-44.

Behrendt, J.C., R. Saltus, D. Damaske, A. McCafferty, C. Finn, D. D. Blankenship, R. E. Bell (1996), Patterns of late Cenozoic volcanic and tectonic activity in the West Antarctic Rift System revealed by aeromagnetic surveys, Tectonics, 15, 660-676.

Bosum W., D. Damaske, N. W. Roland, J. C. Behrendt, R. Saltus (1989), GANOVEX IV Victoria Land/Ross Sea aeromagnetic survey: interpretation of the anomalies, Geol. Jb. E38, 153-230.

Bozzo E., F. Ferraccioli, M. Gambetta, G. Caneva, M. Spano, M. Chiappini and D. Damaske (1999), Recent progress in magnetic anomaly mapping over Victoria Land (Antarctica) and the GITARA 5 survey, Antarctic Science, 11, 209-216.

Cande S. C., J. M. Stock, R. D. Müller and T. Ishihara (2000), Cenozoic motion between East and West Antarctica, Nature, 404, 145-150.

Damaske D. (1994), Aeromagnetic surveys over the Transantarctic Mountains and the Ross Sea area, Terra Antartica, 1, 3, 503-506.

Di Vincenzo G., S. Rocchi, F. Rossetti and F. Storti (2004), ${ }^{40} \mathrm{Ar}-{ }^{39} \mathrm{Ar}$ dating of pseudotachylytes: the effect of clast-hosted extraneous argon in Cenozoic fault-generated friction melts from the West Antarctic Rift System, Earth and Planet. Sci. Lett., 223, 349-364.

Federico L., G. Capponi, and L. Crispini (2006), The Ross Orogeny of the Transartarctic Mountains: a northern Victoria Land perspective, International Journal of Earth Sciences, doi:10.1007/s00531-0050063-5.

Ferraccioli F., M. Gambetta, and E. Bozzo (1998), Microlevelling procedures applied to regional aeromagnetic data: An example from the Transantarctic Mountains (Antarctica), Geophys. Prospect., 46, 177-196.

Ferraccioli F. and E. Bozzo (1999), Inherited crustal features and tectonic blocks of the Transantarctic Mountains: an aeromagnetic perspective (Victoria Land, Antarctica), J. Geophys. Res., 104, 25297-25319.

Ferraccioli F., E. Armadillo, E. Bozzo, E. Privitera (2000), Magnetics and Gravity Image Tectonic Framework of the Mount Melbourne Volcano Area (Antarctica), Phys. and Chem. of the Earth, 25(4), 387393.

Ferraccioli F., E. Bozzo, G. and Capponi (2002), Aeromagnetic and gravity anomaly constraints for an early Paleozoic subduction system of Victoria Land, Antarctica, Geophys. Res. Lett., 29(10), doi:10.1029/2001GL014138.

Ferraccioli F. and E. Bozzo (2003), Cenozoic strike-slip faulting from the eastern margin of the Wilkes Subglacial Basin to the western margin of the Ross Sea Rift: an aeromagnetic connection, Intraplate Strike-slip Deformation, edited by F. Storti, R. E. Holdsworth and F. Salvini, J. Geol. Soc. Spec. Publ. 210, pp.109-133, London.

Finn C., D. Moore, D. Damaske \& T. Mackey (1999), Aeromagnetic Legacy of early Paleozoic subduction along the Pacific margin of Gondwana, Geology, 27, 1087-1090.

Fitzgerald P. (2002), Tectonics and landscape evolution of the Antarctic plate since the breakup of Gondwana, with an emphasis on the West Antarctic Rift System and the Transantarctic Mountains, in Antarctica at the close of a millennium, edited by J.A. Gamble, D.N.B. Skinner and S Henrys, The Royal Society of New Zealand Bulletin 35, pp. 453-470.

Lawver, L.A., and Gahagan, L.M., 1994, Constraints on timing of extension in the Ross Sea region: Terra Antarctica, v. 1, p. 545-552.

LeMasurier W.E. (1990), Late Cenozoic volcanism on the Antarctic plate: an overview, in Volcanoes of the Antarctic plate and southern oceans, edited by W.E. LeMasurier, J.W. Thomson, Antarctic Research Series 48, American Geophysical Union, Washington, DC, pp. 1-19.

Rocchi S., P. Armienti, M. D'Orazio, S. Tonarini, J. R. Wijbrans, G. Di Vicenzo (2002a), Cenozoic magmatism in the western Ross Embayment: Role of mantle plume versus plate dynamics in the development of the West Antarctic Rift System, J. Geophys. Res., $107, \mathrm{~B} 9$.

Rocchi S., A.M. Fioretti, G. Cavazzini (2002b), Petrography, geochemistry and geochronology of the Cenozoic Cape Crossfire, Cape King and No Ridge igneous complexes, (Northern Victoria Land, Antarctica), in Antarctica at the close of a millennium, edited by J.A. Gamble, D.N.B. Skinner and S Henrys, The Royal Society of New Zealand Bulletin 35, pp. 215-225.

Rocchi S., F. Storti, G. Di Vincenzo, F. Rossetti (2003), Intraplate strike-slip tectonics as alternative to mantle plume activity for the Cenozoic rift magmatism in the Ross Sea Region, Antartica. Geol. Soc. London. Spec. Pub., 210: 145-158.

Rocchi S., G. Di Vincenzo and P. Armienti (2005), No plume, no rift magmatism in the West Antarctic rift, Plates, Plumes \& Paradigms, edited by G. R. Foulger and D. L. Natland Anderson, Geol. Soc. of America Special Paper.

Rocchi S., P. Armenti, G. Di Vincenzo, I. Nardini, F. Rossetti and F. Storti (2006), Tight link between Cenozoic magmatism and localregional fault activity in the West Antarctic Rift, Terra Antartica Reports, 12, 73-80.

Rossetti F., F. Lisker, F. Storti, and A. L. Laufer (2003), Tectonic and denudational history of the Rennick Graben (North Victoria Land): Implications for the evolution of rifting between East and West Antarctica, Tectonics, 22(2), 1016

Salvini F., G. Brancolini, M. Busetti, F. Storti, F. Mazzarini \& F. Coren (1997), Cenozoic geodynamics of the Ross Sea region, Antarctica: crustal extension, intraplate strike-slip faulting, and tectonic inheritance, J. Geophys. Res., 102, 24, 669-24,696.

Tonarini S., S. Rocchi, P. Armienti, F. Innocenti (1997), Constraints on timing of Ross Sea rifting inferred from Cenozoic intrusions from Northern Victoria Land, Antarctica, in The Antarctic Region: Geological Evolution and Processes, edited by C.A. Ricci, Siena, pp. 511-521. 